\title{
The antibiotic susceptibility of Mycoplasma hominis
}

\author{
HERBERT J. HARWICK AND F. ROBERT FEKETY, Jr ${ }^{1}$ \\ From the Department of Internal Medicine, University of Michigan Medical School, Ann Arbor, Michigan
}

SYNOPSIS Mycoplasma hominis is now recognized as a human pathogen, but little information regarding its antibiotic susceptibility is available. We therefore tested the susceptibility of 49 isolates of $M$. hominis to 16 antibiotics. Penicillin-like drugs and erythromycin showed no activity whatsoever. Tetracycline and lincomycin were the most active drugs, with chloramphenicol, kanamycin, and streptomycin showing some inhibitory activity. The distinctions between metabolic inhibition, growth inhibition, and mycoplasmacidal endpoints are discussed and defined.

In the past decade Mycoplasma hominis has been recognized as a pathogen in the female urogenital system. The full extent of its role in abortion, postpartum fever, ovarian abscesses, and salpingitis is just becoming known, but there seems little question that it does play some pathogenic role (Harwick, Iuppa, Purcell, and Fekety, 1967; Jones, 1967; Tully, Brown, Sheagren, Young, and Wolff, 1965).

Several studies have already been performed to determine the antibiotic susceptibilities of various mycoplasma species. In 1958 Blythe tested 44 mycoplasma strains isolated from the human urogenital tract against a number of antibiotics (see Klieneberger-Nobel, 1962). Though a large number were probably Mycoplasma hominis, unfortunately these organisms were not actually identified at the time. Blythe's method involved agar dilutions and measured inhibition of mycoplasma growth on the plate. Since then several studies have been performed testing the susceptibility of Mycoplasma pneumoniae (Slotkin, Clyde, and Denny, 1967) in vitro and in vivo but no extensive experience with Mycoplasma hominis has been published. Purcell, Taylor-Robinson, Wong, and Chanock (1966) have described a metabolic inhibition technique for determining antibody response to Mycoplasma hominis which employs micro-techniques and utilizes the inhibition of arginine metabolism and the consequent lack of colour change in the culture as the indicator of the organism's growth inhibition. Taylor-Robinson (1967) has recently used this same method in the determination of antibiotic sensitivities to a number

1Supported by grants nos. AI-00344-01 and FR-053853 from the National Institutes of Health.

Please address reprint requests to Dr F. R. Fekety, Jr at University Hospital, 1405 E. Ann Street, Ann Arbor, Michigan 48104.

Received for publication 17 October 1968. of different mycoplasma species. We have employed a technique similar to this, but have determined both the metabolic inhibition endpoint and the antibiotic concentration at which actual killing took place.

\section{METHODS}

Forty-nine isolates of Mycoplasma hominis identified both biochemically and immunologically using the fluorescent antibody method of Del Giudice, Robillard, and Carski (1967) were tested against 16 antibiotics. Fourteen were obtained from Mr York Crawford at the Great Lakes Naval Station, while the balance (35 isolates) were obtained from patients with pelvic disease studied at The Johns Hopkins Hospital. Of these 35, four were blood isolates, four were amniotic fluid isolates, and the balance were isolated cervical cultures.

All organisms were tested in a broth medium consisting of 8 parts mycoplasma broth base, 2 parts tissue culture select horse serum, and $2 \%$ by volume dialysate of yeast extract. No antibiotics or inhibitors (such as thallium acetate) were employed in the medium. The medium also contained $1 \%$ arginine hydrochloride and $0.5 \%$ phenol red and was adjusted to a $p \mathbf{H}$ of $7 \cdot 0$. One thousand colony-forming units of $M$. hominis were added to each test well in two microtitration plates which contained serial (two-fold) dilutions of penicillin G, ampicillin, methicillin, tetracycline, chloramphenicol, lincomycin, 7-chloro-7-deoxylincomycin, cephalothin, carbenicillin, erythromycin, streptomycin, kanamycin, rifampin, polymyxin B, sodium colistimethate, and vancomycin. Medium and organism control wells were included in each microtitration plate. After inoculation the plates were sealed with cellophane tape and incubated for 72 hours. At 72 hours each was examined for evidence of colour change, indicating metabolic activity of the mycoplasma. The lowest concentration of antibiotic which inhibited colour change was considered the metabolic inhibition endpoint. At this time the plate was shaken gently and each well was subcultured to antibiotic483 
TABLE

METABOLIC INHIBITION AND MYCOPLASMACIDAL ACTIVITY OF VARIOUS ANTIBIOTICS AGAINST Mycoplasma hominis EXPRESSED AS CUMULATIVE PERCENTAGES INHIBITED ${ }^{1}$

\begin{tabular}{|c|c|c|c|c|c|c|c|c|c|c|c|c|}
\hline \multirow{2}{*}{ Antibiotic } & \multirow{2}{*}{$\begin{array}{l}\text { No. of } \\
\text { Strains } \\
\text { Tested }\end{array}$} & \multirow{2}{*}{$\begin{array}{l}\text { Mean } \\
\text { Inhibitory } \\
\text { Concentration } \\
(\mu \mathrm{g} / \mathrm{ml})\end{array}$} & \multicolumn{10}{|c|}{ Sensitivity ( $\mu \mathrm{giml})$} \\
\hline & & & $0 \cdot 2$ & 0.4 & 0.8 & $1 \cdot 6$ & $3 \cdot 1$ & $6 \cdot 2$ & $12 \cdot 5$ & 25 & 50 & 100 \\
\hline
\end{tabular}

Tetracycline

Chloramphenicol

Lincomycin

7-Chloro-lincomycin

Streptomycin

Kanamycin

Rifampin

$\begin{array}{llccc}48(34) & 3 \cdot 2(3.4) & 63(38)^{2} & 80(65) & 84(79) \\ 49(34) & 3 \cdot 2(4 \cdot 96) & 4(0) & 8(0) & 31(0) \\ 49(34) & 0.67(1.9) & 51(12) & 82(41) & 86(68) \\ 49(35) & 0 \cdot 18(0 \cdot 3) & 96(83) & 96(86) & 98(94) \\ 49(34) & 11(44) & - & - & 2(0) \\ 49(34) & 2 \cdot 7(10 \cdot 4) & - & 12(6) & 24(6) \\ 49(34)>100(>100) & - & - & -\end{array}$

\section{8 (82) 94 (85)} 59 (15) 88 (44) 92 (79) 98 (94) 100 (97) $0(100)$ 6 (0) $29(6)$ 63 (26) $78(56)$

2 (0) 4 (0)
$96(85) 98(91) \quad 100(100)-$ $90(68) 94(74) \quad 98(85) \quad \overline{100}(88) \quad \overline{91}(0)$ 00 (97) $0(97)$ $69(26) \quad 82(41) \quad \overline{96}(71) \quad \overline{100}(74)$ 84 (74) $90(85) \quad 100(94) \quad 0(97)$ $6(0) \quad 8(0) \quad 24(0)$ free mycoplasma agar using a horizontal $3 \mathrm{~mm}$ loop, which delivered $0.005 \mathrm{ml}$. The subculture plates were incubated for an additional 72 hours, at which time they were examined for evidence of colonial growth. The lowest concentration of antibiotic from which none or one colony grew on subculture was considered to be the mycoplasmacidal endpoint (98.0\% killing activity).

\section{RESULTS AND DISCUSSION}

Metabolic inhibition endpoints were determined for all 49 strains tested, while mycoplasmacidal endpoints were performed on 35 of these strains. Penicillin G, ampicillin, methicillin, erythromycin, cephalothin, carbenicillin, and vancomycin were inactive against Mycoplasma hominis within the range of concentrations tested. The Table lists the combined antibiotic sensitivities to the seven antibiotics which did demonstrate inhibitory activity. Though mycoplasmacidal endpoints were consistently higher than metabolic inhibition endpoints, these differences were trivial with antibiotics which demonstrated high degrees of activity against the organism, such as tetracycline, lincomycin, and 7-chloro-lincomycin. However, these differences were often quite significant with antibiotics which demonstrated less activity. A point to note is that while erythromycin is exceedingly active against Mycoplasma pneumoniae, it has no demonstrable inhibitory activity against Mycoplasma hominis. Erythromycin has frequently been recommended as a drug of choice in the treatment of Mycoplasma pneumoniae infection, whereas it would apparently be of no value in the treatment of infections caused by Mycoplasma hominis.

A great deal of semantic confusion has entered the literature since the first description of mycoplasmal growth inhibition due to specific antiserum by Edward and Fitzgerald (1954). The technique they described involved actual inhibition of growth on agar plates; the same term, however, has since ${ }^{\omega}$ been applied to the measurement of decreases in $\triangle$ colony-forming unit counts from a test system. In practice this last is a measurement of the mycoplasmacidal or killing activity of the test system, not growth inhibition. The confusion has been further\% heightened by the appearance of the metabolic.. inhibition test as a laboratory tool. Strictly speaking, this measures neither killing nor growth inhibition, but rather alterations in cumulative metabolic activity up to a given point in time (Purcell et al, 1966). ٌٌ Despite the obvious difference in the method of $\stackrel{\mathbb{Q}}{\varrho}$ endpoint determination, many authors seem to use $\overrightarrow{\vec{P}}$ the terms 'growth inhibition' and 'metabolism? inhibition' interchangeably or actually to apply one name to the other test. Though our studies involvedo antibiotics rather than antibodies, one would suspect that differences between inhibition and killing would? still vary even in another test system. Certainly one $\frac{O}{3}$ would be dubious about any attempt to compare numerically results determined by metabolic inhibi-윽 tion.

In the context of antibiotic sensitivity testing the ? two endpoints may be analogous to bacteriostatic $\frac{D}{O}$ and bactericidal endpoints, respectively. Those antibiotics which are bactericidal (such as the $\mathcal{N}^{-}$ penicillins) and act on the cell wall have little activity against Mycoplasma hominis, while those antibiotics known to have primarily ribosomal sites $\omega$ of action and to be only bacteriostatic (such as? tetracycline and linomycin) are extremely effective mycoplasmacidal agents.

When Mycoplasma hominis infections are to be treated with antibiotics, our data suggest that tetracycline or lincomycin would be the drugs of choice. Chloramphenicol, streptomycin, and kana- $\frac{?}{\mathrm{~N}}$ mycin are less active, but effective levels for many strains might be reached clinically. Penicillin and itse analogues are without value. 
REFERENCES

Del Giudice, R. A., Robillard, N. F., and Carski, T. R. (1967). J. Bact., 93, 1205.

Edward, D. G.ff., and Fitzgerald, W. A. (1954). J. Path. Bact., 68, 23. Harwick, H. J., Iuppa, J. B., Purcell, R. H., and Fekety, F. R., Jr (1967). Amer. J. Obstet. Gynec, 99, 725.

Jones D. M. (1967). J. clin. Path., 20, 633.
Klieneberger-Nobel, E (1962). London, 109.

Purcell, R. H., Taylor-Robinson, D., Wong, D. C., and Chanock, R. M. (1966). Amer. J. Epidem., 84, 51.

Slotkin, R. I., Clyde, W. A., Jr, and Denny, F. W. (1967). Ibid, 86, 225.

Taylor-Robinson, D. (1967). Postgrad. med. J., 43 (suppl), 100.

Tully, J. G., Brown, M. S., Sheagren, J. N., Young, V. M., and Wolf, S. M. (1965). New Engl. J. Med., 273, 648.

\section{The May 1969 Issue}

\section{THE MAY 1969 ISSUE CONTAINS THE FOLLOWING PAPERS}

Skin carriage of the Micrococcacae w. C. C. NOBLE

Contamination of virological tissue cultures with a species of free-living soil amoeba DAVID P. CASEMORE

Haemophili from eyes H. R. INGHAM and D. C. TURK

Serotyping and the Dienes reaction on Proteus mirabilis from hospital infections J. de Louvors

Review of current methods for the detection of Trichomonas in clinical material J. HESS

The action of light on culture media PAMELA M. WATERWORTH

Recommended scheme for the evaluation of instruments for automatic analysis in the clinical biochemistry laboratory

Quantities and units in clinical chemistry R. DYBKAER

The urinary calcium/creatinine ratio as a measure of urinary calcium excretion M. R. WILLS

Interference from the presence of other substances in detecting and determining barbiturates in biological material S. L. TOMPSETT

Aetiology of extrahepatic epithelial iron deposits in siderosis in Bantu W. M. BUCHANAN

Determinations of iron in solutions containing iron complexes G. B. TENNANT and D. A. GREENMAN

Effects of three cobra venoms on blood coagulation, platelet aggregation, and fibrinolysis N. MACKAY, J. C. FERGUSON, and G. P. MCNICOL

Effect of gaboon viper (Bitis gabonica) venom on blood coagulation, platelets, and the fibrinolytic enzyme system C. D. FORBES, A. G. G. TURPIE, J. C. FERGUSON, G. P. MCNICOL, and A. S. DOUGLAS

Economic and laboratory considerations in screening for vitamin $\mathbf{B}^{12}$ deficiency in psychiatric practice $\mathrm{J}$. SWANSON BECK, AUDREY A. DAWSON, J. G. HENDERSON, and R. W. STRACHAN
A comparison of the Monospot with the Paul-Bunnell test in infectious mononucleosis and other dissases B. SEITANIDIS

Monospot: a differential slide test for infectious mononucleosis VIVIAN BASSON and A. A. SHARP

The cellular infiltrate in Hashimoto's disease and focal lymphocytic thyroiditis M. HARRIS

Immunofluorescent localization of Tamm-Horsfall mucoprotein in human kidney J. K. MCKENZIE and E. G. MCQUEEN

The problem of 'chronic mastitis' with epitheliosis J. B. MACGILLIVRAY

Gliomatosis peritonei caused by ovarian teratoma R. W. FORTT and I. K. MATHIE

Pathology and survival in operable cases of giant-cell carcinoma of the lung ALEXANDER KENNEDY

Pulmonary calcification in viral pneumonia E. L. JONES and A. H. CAMERON

Symposium on thrombolytic therapy

\section{Technical methods}

Collection of urine from women for bacteriological examination K. B. LINTON and W. A. GILLESPIE

Estimation of barium sulphate in faeces by emission flame photometry MATTHEW DICK

Device for eluting proteins from starch gel by freezing and thawing T. R. C. BOYDE

Letter to the Editor

Book reviews

Copies are still available and may be obtained from the PUBLISHING MANAGER, BRITISH MEDICAL ASSOCIATION, TAVISTOCK SQUARE, W.C.1. 1, price 21s, 